TECHNICAL TRANSACTIONS 9/2018 ARCHITECTURE AND URBAN PLANNING

DOI: $10.4467 / 2353737$ XCT.18.127.8966 SUBMISSION OF THE FINAL VERSION: 27/7/218

\author{
Krystian Banet (iD) orcid.org/0000-0002-9560-483X \\ kbanet@pk.edu.pl \\ Faculty of Civil Engineering, Cracow University of Technology
}

Ewelina Stypułkowska (D) orcid.org/0000-0001-7741-4242

stypulkowska.e@gmail.com

Faculty of Environmental Engineering, Cracow University of Technology

\title{
THE ROLE OF THE VISTULA RIVER IN THE SPATIAL DEVELOPMENT \\ OF RIVERINE RESIDENTIAL DISTRICTS IN CRACOW
}

\author{
ROLA WISEY W ROZWOJU PRZESTRZENNYM \\ NADRZECZNYCH DZIELNIC MIESZKANIOWYCH W KRAKOWIE
}

\begin{abstract}
An important factor in the location of the first human settlements was access to a river. Connected with industrialization, the progressive process of turning the city away from rivers caused the degradation of watercourses and their surroundings. Degraded rivers have become a shameful problem and a barrier to intensively developing cities. In the 21 st century, the advantages of well-developed boulevards were recognized. This article analyzes the role of the river in the urban spatial development and public spaces related to the river. In addition, opportunities for the improvement of riverside urban spaces are presented on the example of the area of Stare Dębniki and Salwator in Cracow. Detailed variants were developed as part of the Przepis na miasto workshops.
\end{abstract}

Keywords: city, river, boulevard, spatial development, public space

\section{Streszczenie}

Ważnym czynnikiem lokalizacji pierwszych osad ludzkich był dostęp do rzeki. Związany z industrializacją, postępujący proces odwracania się miasta od rzek spowodował degradację cieków i ich otoczenia. Zdegradowane rzeki stały się wstydliwym problemem i barierą dla intensywnie rozwijających się miast. W XXI wieku zaczęto dostrzegać zalety dobrze zagospodarowanych bulwarów. W niniejszym artykule dokonano analizy roli rzeki w rozwoju przestrzennym miast i przestrzeni publicznych związanych z rzeką. Ponadto, przedstawiono możliwości poprawy nadrzecznych przestrzeni miejskich na przykładzie obszaru Starych Dębnik i Salwatora w Krakowie. Szczególowe warianty opracowane zostały w ramach warsztatów Przepis na miasto.

Słowa kluczowe: miasto, rzeka, bulwar, planowanie przestrzenne, przestrzeń publiczna 


\section{The role of the river in the development of a settlement}

The rivers have long been influenced by settlements. The development of cities took place on the banks of rivers, and metropolises formed in the basins. The reason for this was the fact that the river was an indispensable factor for human and animal life. Rivers were also an important element of the defense system of cities, they supported communication and trade. Rivers also played an important role in removing urban pollution. The vicinity of the river was a significant influence on the economic development of the cities near it [8].

From the point of view of history, the link between the location of cities and their dependencies on the river is undeniable. The river in the vicinity of the city brought with it dangers like floods. Nevertheless, the river played a very important role in the development of many cities. The analysis of the oldest medieval cities allows to conclude that differences between them in the manner of development result from the chosen location. The analysis of maps of medieval cities allows to distinguish nine types of city locations in connection with the river. The characteristics of the location of historical settlement complexes on the river is contained in Table 1 [8].

Analyzing the spatial development of riverside cities, it can be noticed that the natural environment strongly influenced their shape and spatial extent. Initially, cities were built on one bank of the river. The reason for this were defense issues. For some cities, the river did not constitute a barrier to spatial development; for others, it was an obstacle [8]. In most cases, as time passed, areas designated for the city ceased to be sufficient. Economic growth, demographic growth and flood hazards contributed to moving beyond the scope of old urban centers. The cities gradually began to consist of many settlement units, in which the river affected the plan and character of the development. The first suburbs were absorbed on the same side of the river as the city. The second in the order of the cities were included undeveloped suburban areas. Connected areas in one settlement complex were often characterized by a separate character of development or compactness of buildings. This created an impression of urban chaos and incoherence [8].

Table 1. Characteristics of the location of historical settlement complexes on the river

\begin{tabular}{|c|c|c|}
\hline $\begin{array}{c}\text { On the island formed by the } \\
\text { arms of the river }\end{array}$ & $\begin{array}{c}\text { Example } \\
\text { Wroclaw on the Oder } \\
\text { Poznan on the Warta } \\
\text { Paris on the Seine }\end{array}$ \\
\hline $\begin{array}{c}\text { On an elongated promontory, } \\
\text { surrounded on three sides by } \\
\text { a river bed }\end{array}$ & $\begin{array}{c}\text { Besancon on the Doubs } \\
\text { Between the river and its } \\
\text { tributary }\end{array}$ & $\begin{array}{c}\text { Lyon on the Saona and } \\
\text { Rhone }\end{array}$ \\
\hline
\end{tabular}




\begin{tabular}{|c|c|c|}
\hline $\begin{array}{c}\text { Between the lake and the } \\
\text { river's backwaters }\end{array}$ & $\begin{array}{c}\text { Geneva on the Rhone } \\
\begin{array}{c}\text { At the mouth of the river to } \\
\text { large water bodies }\end{array}\end{array}$ & $\begin{array}{c}\text { Szczecin on the Oder and } \\
\text { next to Szczecin Lagoon }\end{array}$ \\
\hline $\begin{array}{c}\text { On the hill above the river } \\
\text { or on the high terraces of its } \\
\text { valley }\end{array}$ & $\begin{array}{c}\text { Warsaw on the Vistula } \\
\text { Cracow on the Vistula } \\
\text { Prague on the Vltava }\end{array}$ \\
\hline $\begin{array}{c}\text { Place where the river crosses } \\
\text { with an important land trade } \\
\text { route }\end{array}$ & $\begin{array}{c}\text { Torun on the Vistula } \\
\text { Jaroslaw on the San } \\
\text { Przemysl on the San }\end{array}$ \\
\hline $\begin{array}{c}\text { Mocation in the valley, mostly } \\
\text { in the overflow terrace }\end{array}$ & & $\begin{array}{c}\text { Bilbao on the Nervion } \\
\text { Gdansk on the Motlawa }\end{array}$ \\
\hline
\end{tabular}

(Source: [8])

\section{The importance of the Vistula in shaping Cracow}

In the case of Poland, not all rivers were a factor in the development of urban centers. They influenced the local settlement system to varying degrees [3]. Vistula had a great significance in shaping the cities in Poland. Cracow was at its bank. The city was located on the Wawel Hill at the foot of the Vistula River and on the terraces at the mouth of the Rudawa and Prądnik. It was located at the intersection of roads. It was one urban organism. In the midnineteenth century, the city was surrounded by a ring of fortifications. Cracow developed within the limits set by defensive walls, but its dynamic growth and the development of its urban functions influenced the revival of the settlements located in its immediate vicinity: Kazimierz and Kleparz [5]. Rudawa was of great importance to Cracow. The original channel of the Rudawa ran along today's $3^{\text {rd }}$ May Avenue, creating numerous backwaters in the area of Blonia, joining at the confluence of today's streets: Wenecja and Garncarska with 
Mlynowka Krolewska, to reach the Vistula along today's Retoryka street [17]. Very soon, the residents noticed that Rudawa could be used economically. Already in the thirteenth century, Mlynowka Krolewska was created, an artificial riverbed directing the river to the Dominican monastery within the city. It was also part of the city's fortification, providing security. It is worth mentioning that in the moat and in the upper reaches of Mlynówka, i.e. above the water intake, fish were raised. Their presence was not irrelevant there. Firstly, it allowed to follow the purity of the watercourses (the fish die if the water was too polluted) [16]. Second, it was a reservoir of food in the event of a siege of the city. Importantly, the water from the Rudawa was widely used by residents for everyday activities. Despite the proximity of such a large river as the Vistula, Rudawa was more important at that time. All because of the Vistula flowing too low. Rudawa had a much larger drop, and hence, more energy that could be used [16]. It was additionally intensified by damming the water with a weir in Mydlniki. The Vistula was a huge pool, and it could be not tamed it as much as the smaller Rudawa.

Due to the location of Cracow, floods were a big problem for its residents. The $19^{\text {th }}$ and $20^{\text {th }}$ centuries were the most destructive. Zygmunt August already issued a ban on construction along the Młynówka river to protect the people from the tragic consequences of great water. Only industrial plants could be located there. Successive kings upheld these bans, but they were systematically broken by the inhabitants. The decision to close the Mlynówka river bed was made after the flood in 1903, during which its backwaters caused the most damage in the center of Cracow. Another of the activities leading to the remoteness of the watercourses from the city after the tragic flood in 1903 was redirecting the Rudawa in 1907-1912 to its current embanked canal that flows to the Vistula on the Rodlo Boulevard near the Norbertine monastery $[5,16]$. It was established long before this, because in the seventeenth century, it was supplying water to the monastery farms and breeding ponds. The previous Rudawa channel has been buried in this section. In the place of the closed trough, a low-alley alley was created, separating two street routes [12]. Thanks to the drainage and protection works carried out on the Vistula and Rudawa, new areas, which were located in the vicinity of the central part of the city, were obtained. These areas became a release from the flood threat and could be used for investment and construction purposes. For years, Cracow has moved away from the river. The only areas closely related to the river are the Vistula boulevards. The spatial development of Cracow has been unrelated to the Vistula for years. The desire to connect the Vistula residential districts with the Vistula became the reason for writing the article.

\section{Forms of urban public space connected with the river}

In the second half of the $20^{\text {th }}$ century, the process related to the revitalization of riverside areas was initiated in the development of riverside cities. It consists of addressing cities to the river [6]. In recent years, fashion on the quay has taken on a global dimension and changed the way of thinking about water and its neighborhood. Riverside areas are subject to discussions, analyzes and undertakings regarding urban development planning, urban planning and architecture [4]. The riverside areas in the city are areas that accompany the river in its 
immediate vicinity and depend on its benefits and threats. This concept includes developed fragments of banks that lend space to the river, creating its functional and scenic frame. The outline of riverside areas is marked by the adjacent buildings and mass of greenery, or other compact sets of objects that can be considered a wall of a landscaped interior stretching along the river [2]. At present, the renewal of spatial and functional relations between the city and the river is one of the important problems of riverside cities development [7]. The evolution of city-river relations relies on the cities turning in front of the river by reusing (revitalizing) the riverside areas and shaping new functional and spatial relationships with the river [4]. The revitalization of riverside areas is one of the important development trends observed in many riverside cities and the challenge facing these cities in the $21^{\text {st }}$ century. The revitalization of riverside areas is a response to the process of earlier degradation of these areas. The direct cause of the transformation of riverside areas is also the growing social demand for such individual places. In European port and riverside cities, the importance of riverside areas and recognition of their location attractiveness has been rediscovered. A significant role of the river and the coast in the identification of cities, large cultural values and historical rivers as well as riverside areas have been noticed [6]. Among the model projects of the revitalization of urban riverside areas are: Bilbao, Manchester, Amsterdam or London. The best large-scale urban projects come from Lyon, Hamburg and Berlin [4, 10].

The revitalization of the banks of the Nervion river in Bilbao is undoubtedly the most popular example of returning the river to the city. To stimulate the city, a plan was created to transform the former shipyard's grounds into a cultural and entertainment center. In

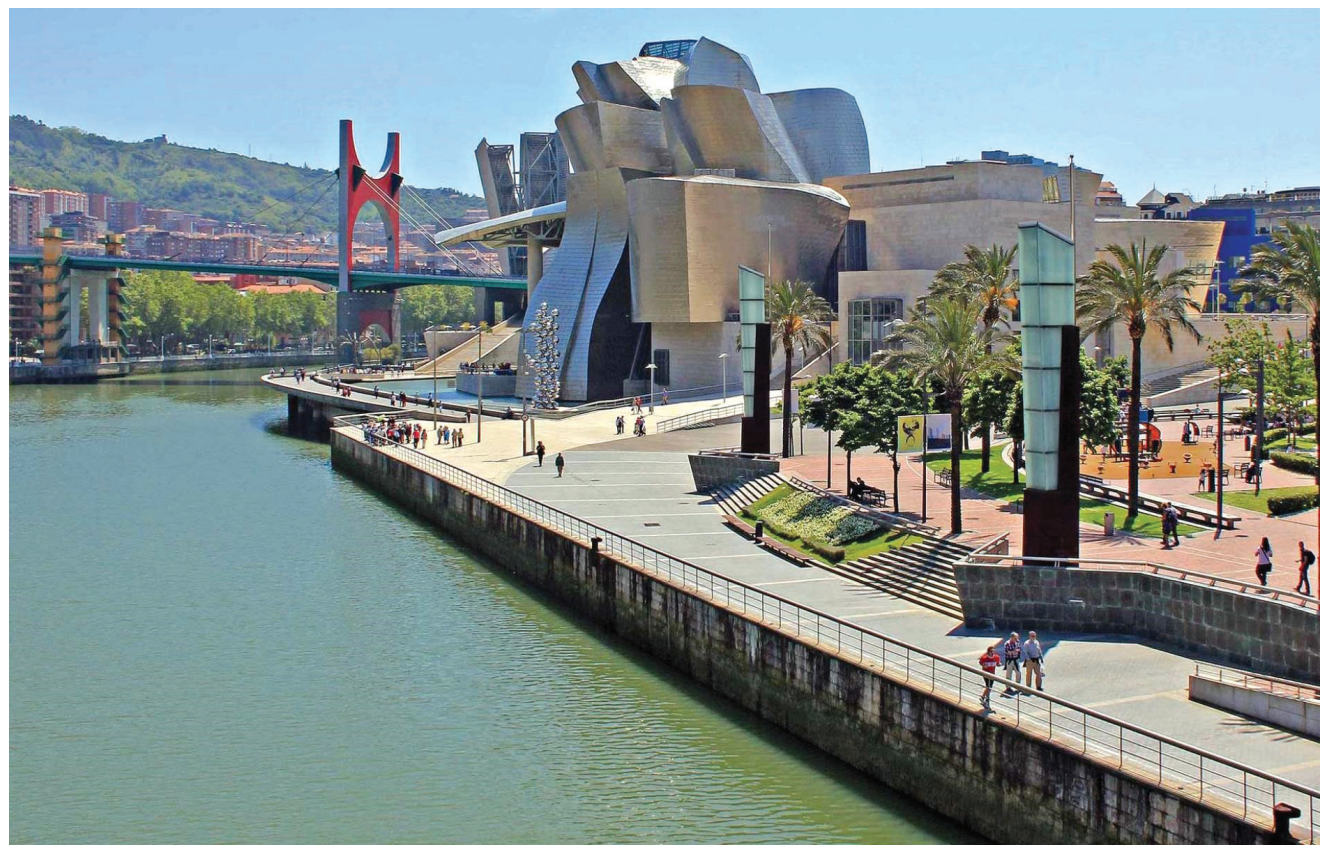

Fig. 1. Guggenheim Museum in Bilbao

(source: [18]) 
addition, it was supported by a number of other activities, such as the renewal of housing in the city center and the expansion of the communication node. The quay was developed with a diversified function: residential, service and cultural (Guggenheim Museum, Figure 1) [9]. This contemporary object caused that all space in the immediate vicinity of the river came alive. The museum caused that the Nervion river boulevard became a new quality space, attracting residents due to new, attractive places of residence and work, but also became a tourist attraction. This 'revival' of the city was referred to as the 'Bilbao effect' [1].

Another example of good practices in dealing with riverfronts is Hamburg. The river has a different role in Hamburg than in Cracow because it is a port city, despite Hamburg being one of the best examples in Europe on how to deal with a river. The idea of a new inner-city district was conceived soon after the fall of the Wall and the Iron Curtain. Before the publication of the blueprint for HafenCity, the Masterplan, in 2000, important fundamentals had already been put in place in the 1990s. HafenCity Hamburg is a project of urban regeneration where the 'Grosser Grasbrook' area of the former Hamburg free port is being revitalized with new hotels, shops, office buildings, and residential areas. The project is considered the largest urban redevelopment project in Europe by landmass (approximately 2.2 square kilometers) [15]. An example of the restoration of water to the city as the main element of spatial composition is undoubtedly the Santiago Calatrava City of Arts and Sciences located in the drained bed of the Turia River in Valencia. The area of almost 360 square meters has been designed with futuristic buildings, which house an oceanarium, a science museum and an opera, surrounded by swimming pools and exotic gardens [9].

\section{Riverine area development in the Cracow Urban Programs}

The future of Polish cities depends on the program assumptions of the city authorities and their implementation. Cracow residents have been observing the creation of numerous new housing complexes, public buildings and service facilities for several years. At the same time, their awareness of rational land use and sustainable development has increased. Residents have higher expectations in work and residential places, reliable transport system, but also friendly public spaces and access to decorated urban greenery. Cracow, like other large cities in Europe and around the world, faces significant development challenges.

Cracow Development Strategy "I want to live here. Cracow 2030." is a document defining the basic directions of socio-economic development over a longer period of time. It is one of the most important documents from the Cracow Urban Programs, which defines the following strategic purposes [13]:

1. Cracow as an open and harmonious metropolis of international significance in the areas of: innovation, science, economy and culture.

2. Cracow as a city developing a knowledge-based economy.

3. Cracow as a modern metropolis that is creative as well as using cultural potential.

4. Cracow as a city that is friendly to life.

Strategia Rozwoju Krakowa Tu chcę żyć. Kraków 2030 - transl. note. 
5. Cracow with a strong local self-government community of Cracow residents.

6. Cracow as a modern managed metropolis.

The implementation of the fourth purpose is focused on the creation of new public spaces, improvement of environmental quality standards and urban space revitalization. This document [13] contains a number of strategic projects, including some directly related to the Vistula River:

- creation of river parks (rivers: Vistula, Drwinka, Dłubnia, Wilga, Sudół Dominikański, Białucha),

- construction of the Kazimierz - Ludwinów shared cyclist-pedestrian footbridge,

- creation of Zabłocie Park - "Wisła Station",

- revitalization of areas near the Kotlarski Bridge - Podolski Boulevard,

- construction of "Marina Krakowska".

Study of the Conditions and Directions of the Spatial Management of a Cracow Commune $^{2}[14]$ is, apart from the Cracow Development Strategy, the most important planning document of the commune. The study is prepared in order to determine the spatial policy of the commune, including local spatial development regulations. The study regulations are binding for the prepared local spatial development plans, thanks to which the vision included in the study affects local regulations and shapes the commune development. The study implements one of the basic local government responsibilities, which is creating the spatial order which is the basis for the Cracow development.

Study of the Conditions and Directions of the Spatial Management of a Cracow Commune [14] defines the directions of changes in the development of areas located in the urban zone:

- intensification of investing with preservation and protection of existing public greenery complexes, city squares and green zones,

- modernization of degraded areas with replacement or rehabilitation of buildings and recomposition of urban layouts,

- ordering extensively used space, threatened by urban chaos through land reparcelling and consolidation,

- use of preserved open areas, especially those located along rivers and streams, for shaping publicly available city parks,

- preservation of existing structures with high cultural values by consolidating historically shaped urban layouts and maintaining the architectural character of development proper to individual districts.

The main elements forming the spatial structure of the city are public open spaces. Open areas are primarily those that are or will play a role not only in the natural environment, but first and foremost in the public. Over the last few years green areas have been significant in the Cracow spatial policy. In the Study of the Conditions and Directions of the Spatial Management of a Cracow Commune defines main directions of green areas development:

- forming the municipal public greenery system based on existing natural resources,

- the arrangement of green areas as public spaces with high aesthetic, natural, functional and landscape values,

2 Studium uwarunkowań i kierunków zagospodarowania przestrzennego Miasta Krakowa - transl. note. 
- improvement of legal protection of areas with the highest natural and landscape values,

- forming the spatial connectivity of pedestrian and bicycle routes of public green spaces and open areas, with particular emphasis on riverside greenery within river parks.

On 1 July 2015, the new administrative unit (the City Green Board ${ }^{3}$ ) was established in Cracow. The unit was created with the aim of taking care of almost all green areas in Cracow: parks, forests, green areas and squares, greenery estates, road lanes and Vistula Boulevards. In 2017, a comprehensive document was enacted, taking into account only greenery. 'Directions for the development and management of green areas in Cracow for 2017-2030 ${ }^{4}$ [11] defines local development policy for green areas. As in the Study of the Conditions and Directions of the Spatial Management of a Cracow Commune, in this document, the Vistula River was distinguished and the Vistula River Park was planned. It is a collection of projects whose common denominator is the reconstruction or revitalization of coastal areas of the Vistula River. These include projects of key importance for the development of metropolitan functions of Cracow such as: Congress Center, Music Center, Zabłocie Boulevards (public spaces linking the Cracow-Zabłocie railway station with the new Zabłocie museums and housing and service complexes built under revitalization of post-industrial areas) - connected by attractive pedestrian and bicycle routes and other public spaces (squares, view terraces, mini-park sequences, etc.). Significant components of the Vistula River Park project will be actions leading to the revitalization of Stare Podgórze and the continuation of the revitalization of Kazimierz. This collection of projects will also include projects to revitalize the space of squares, including the square in front of Galeria Kazimierz (from the Vistula boulevards) and to create an attractive park space integrating the planned Music Center with boulevards on the Vistula.

\section{City facing the river-Przepis na miasto workshop}

In May 2017, a team from the Faculty of Civil Engineering of the Cracow University of Technology ${ }^{5}$ organized the Przepis na miasto ${ }^{6}$ multidisciplinary workshop. A group of students from the Cracow University of Technology, Cracow University of Economics, Wrocław University of Science and Technology, University of Economics in Katowice, Adam Mickiewicz University in Poznań and European Students of Industrial Engineering and Management participated in the workshop. The end products of the workshop were six charts and mockups of the Stare Dębniki and Salwator in Cracow particular area parts. The fact that the work had a multidisciplinary character was crucial - the students represented branches of engineering associated with transport, spatial management as well as urban and

\footnotetext{
Zarząd Zieleni Miejskiej - transl. note.

Kierunki Rozwoju i Zarządzania Terenami Zieleni w Krakowie na lata 2017-2030 - transl. note.

WIL PK - Polish abbreviation, transl. note.

The workshop took place between 18-20.05.2017. Krystian Banet and Ewelina Stypułkowska were organising committee chairmen. The workshop was organized by KNSK Student Scientific Association of Transporartion Systems (Koło Naukowe Systemów Komunikacyjnych - transl. note).
} 
architectural design across two levels of higher education (Bachelor, Master). Students' work was supported by a panel of experts: Andrzej Szarata, Tomasz Kulpa, Marek Bauer, Mariusz Dudek, Aleksandra Faron, Katarzyna Nosal, Kinga Racoń-Leja, Agnieszka Szumilas, Ada Wolny. The overall goal of the workshop was an attempt to connect two Vistula river banks, to analyze the urban transport system integration and to propose changes in the selected degraded public spaces.

The common issue of the six projects was to transform the river from a barrier into a connector. The common idea of all of the groups was the construction of the Stare Dębniki - Salwator shared cyclist-pedestrian footbridge. The large distance between the nearest bridges (the Dębnicki and the Zwierzyniecki bridges) was an argument for creating such a connection. The footbridge would increase the accessibility of the Vistula banks, make it easier to move around the city, but would also serve as a vantage point. As it was mentioned in paragraph 3, one of the strategic projects [13] is the construction of the Kazimierz - Ludwinów shared cyclist-pedestrian footbridge. Students pointed to the need for an additional shared cyclist-pedestrian footbridge between Stare Dębniki and Salwator.

The creation of the Vistula river park was also a common issue of the six projects. As it was mentioned in paragraph 3, the creation of the Vistula river park is one of the strategic projects pointed out in the Cracow Development Strategy [13]. Due to it and the Study of the Conditions and Directions of the Spatial Management of a Cracow Commune [14], in which it is said that Cracow should be developed using preserved open areas, especially those located along rivers and streams, for shaping publicly available city park, all groups proposed some ideas for the Vistula boulevard.

The Discover yourself again ${ }^{7}$ conceptual design assumed the development of the southern Vistula river bank, modeled on Japanese gardens. The garden would be divided into several parts. Each of them would use the experience of one of the four senses: touch, hearing, taste/smell and vision. The goal would be achieved through the implementation of different surfaces, flora or water elements. The garden would refer to the Manggha Museum of Japanese Art and Technology located nearby. It would be an extension of the museum's offer and a presentation of the external elements of Japanese culture. The implementation would not only have a functional, aesthetic and recreational aim, but also an educational one.

The next workshop variant, which adapts Stare Dębniki area to the mobility needs of sight-impaired people, is the Let's make noise ${ }^{8}$ conceptual design. In this solution, the authors focused on the Rynek Dębnicki square. The concept assumed the revitalization of the public space. In this proposal, the removal of road lanes around the Rynek Dębnicki square was intended to improve pedestrian safety. A reduction in private car traffic has permitted to create friendly public space. The concept assumed the revitalization of the municipal greenery and an introduction of a green pergola on the western Rynek Dębniki square side. In the central part of the Rynek Dębnicki square, the authors designed an interactive board. The main

Authors: Piotr Bielański (CUT), Anna Saletra (CUT), Maciej Górz (CUE), Kinga Kasprzyca (WUST), Alicja Walczak (CUT).

8 Authors: Jakub Salach (CUT), Małgorzata Stec (CUT), Maciej Pilny (WUT), Justyna Mazur (CUT), Natalia Kobza (ESIEM). 


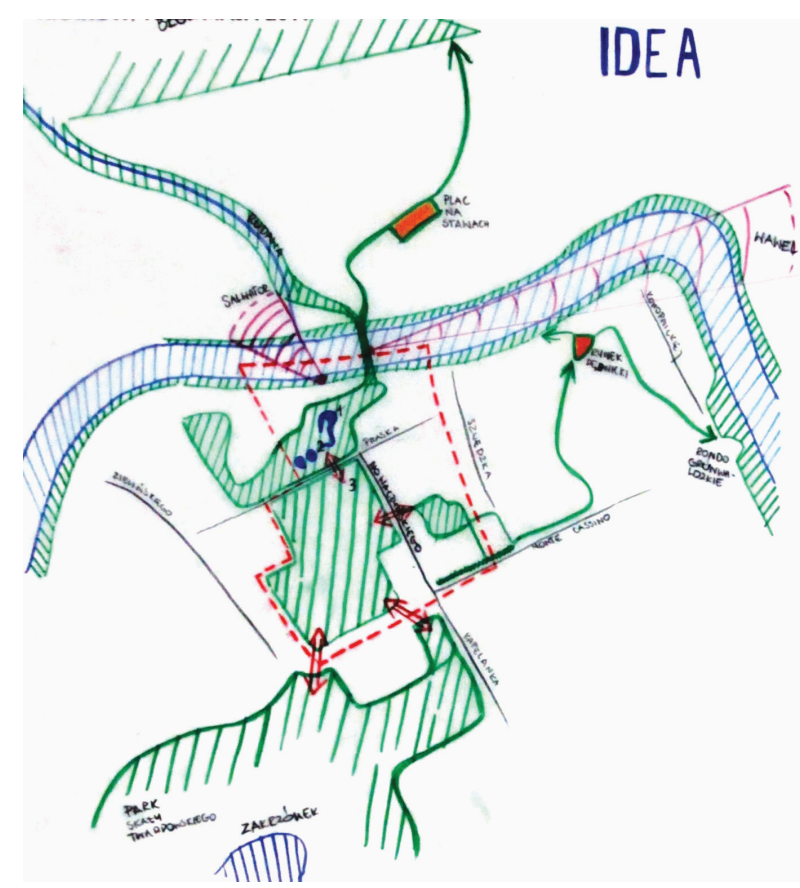

Fig. 2. The Vistula Garden - design concept developed as a part of the Przepis na miasto workshop (by: Ewa Dyk, Marcelina Smolarczyk, Paweł Ulfik, Aleksandra Fira, Gabriela Frań)

aim of the board is to learn and play using sound experiences, such as clash, crackle, flutter, hiss, jingle, splash, twitter, whistle. The project also involves the installation of demountable wooden platforms on the river bank. The platforms would be an extension of the city to the river. The city would merge with the river. The shoreline would not be a rigid border.

The third idea was the Vistula Garden', which assumed the use of the proposed footbridge as a link between the green areas located on the opposite banks of the Vistula. The footbridge would connect the green areas of the Dębniki allotments, Dębnicki Park, Vistula boulevards with the extension to the Rudawa boulevards (Figure 2). The project would not only have a functional and recreational purpose, but also an educational one. On the right Vistula riverbank, near Dębnicki Park, the creation of the educational Center of Water was proposed (Figure 3). The Water Center would educate on how important water is, and how you can purify water using natural methods. Similarly to the Let's make noise, an assembly of demountable wooden platforms on the bank of the Vistula was established. As it was mentioned in paragraph 3, one of the strategic projects [13] is the construction of "Marina Krakowska". The students proposed to place it on the right Vistula riverbank in the front of Lasocki Palace.

Authors: Ewa Dyk (WUST), Marcelina Smolarczyk (CUT), Paweł Ulfik (UEK), Aleksandra Fira (CUT), Gabriela Frań (CUT). 


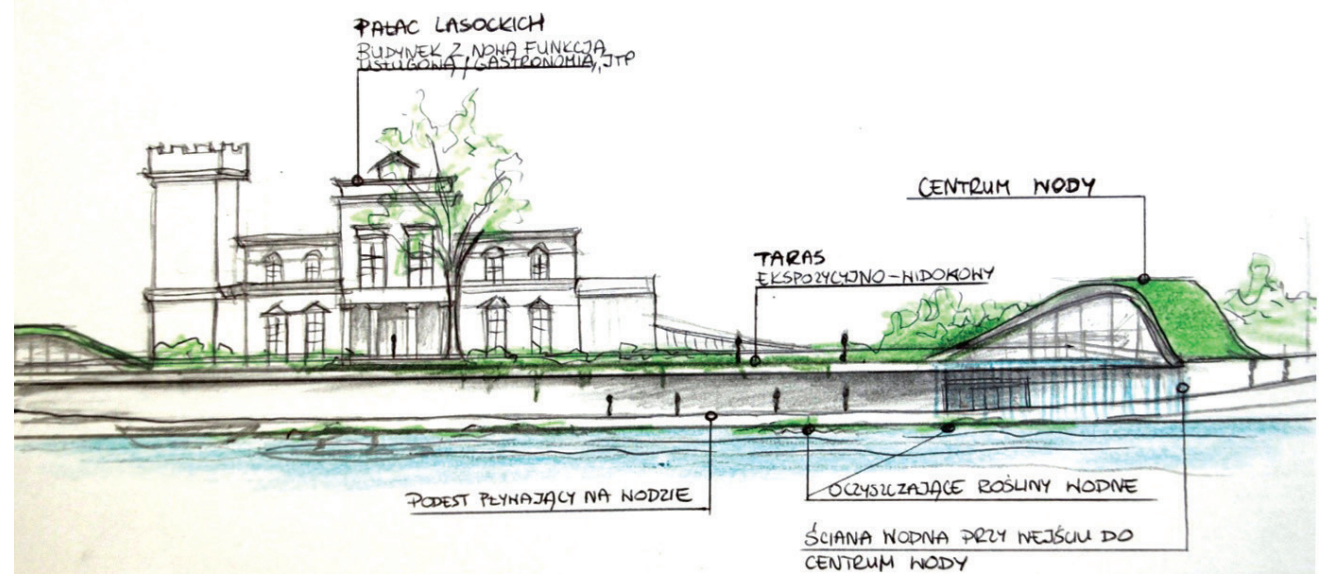

\section{PrzEKROJ PRZEZ KEADKG}

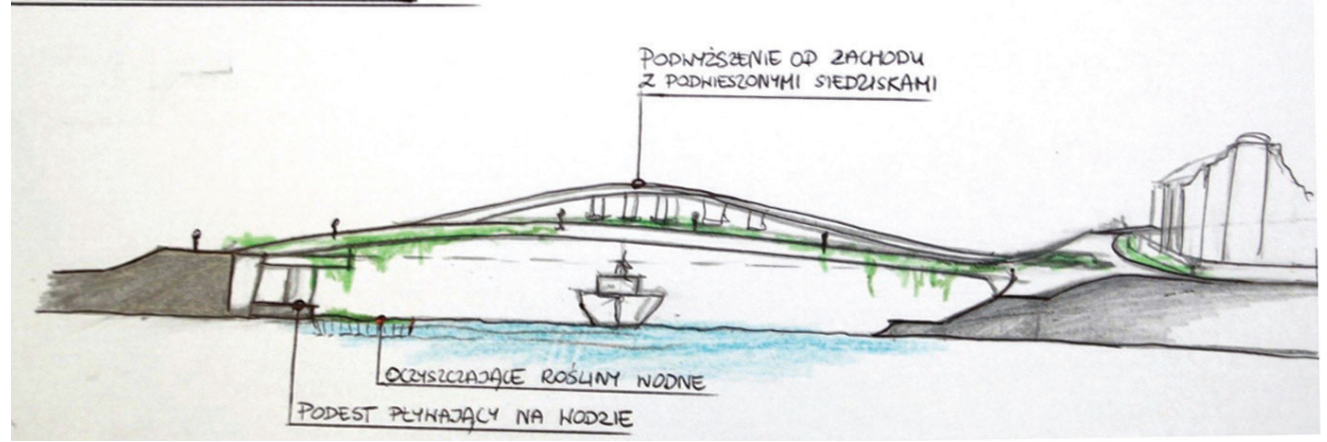

Fig. 3. The Vistula Garden - design concept developed as a part of the Przepis na miasto workshop (by: Ewa Dyk, Marcelina Smolarczyk, Paweł Ulfik, Aleksandra Fira, Gabriela Frań)

The Entangled Salwator ${ }^{10}$ (Figure 4) is the last project presented in the article. The concept assumed the use of the Vistula tributary potential - the Rudawa river. The main dominant element of the area is the Norbertine Sisters Priory and the Salwator terminus. Accurate build-up limited the possibilities of introducing new functions. The authors relied on improving the existing state and introducing as much greenery as possible. Hence the concept of greening the terminus by assembling pergolas and climbing plants (Figure 4). On the Rudawa boulevards, it was proposed to create walking and cycling routes in the shape of wavy lines with numerous seats.

10 Authors: Andrzej Bąk (CUT), Marcin Zaleski (CUT), Paulina Stopka (WUST), Paulina Ziętek (UEK), Angelika Spendel (CUT). 


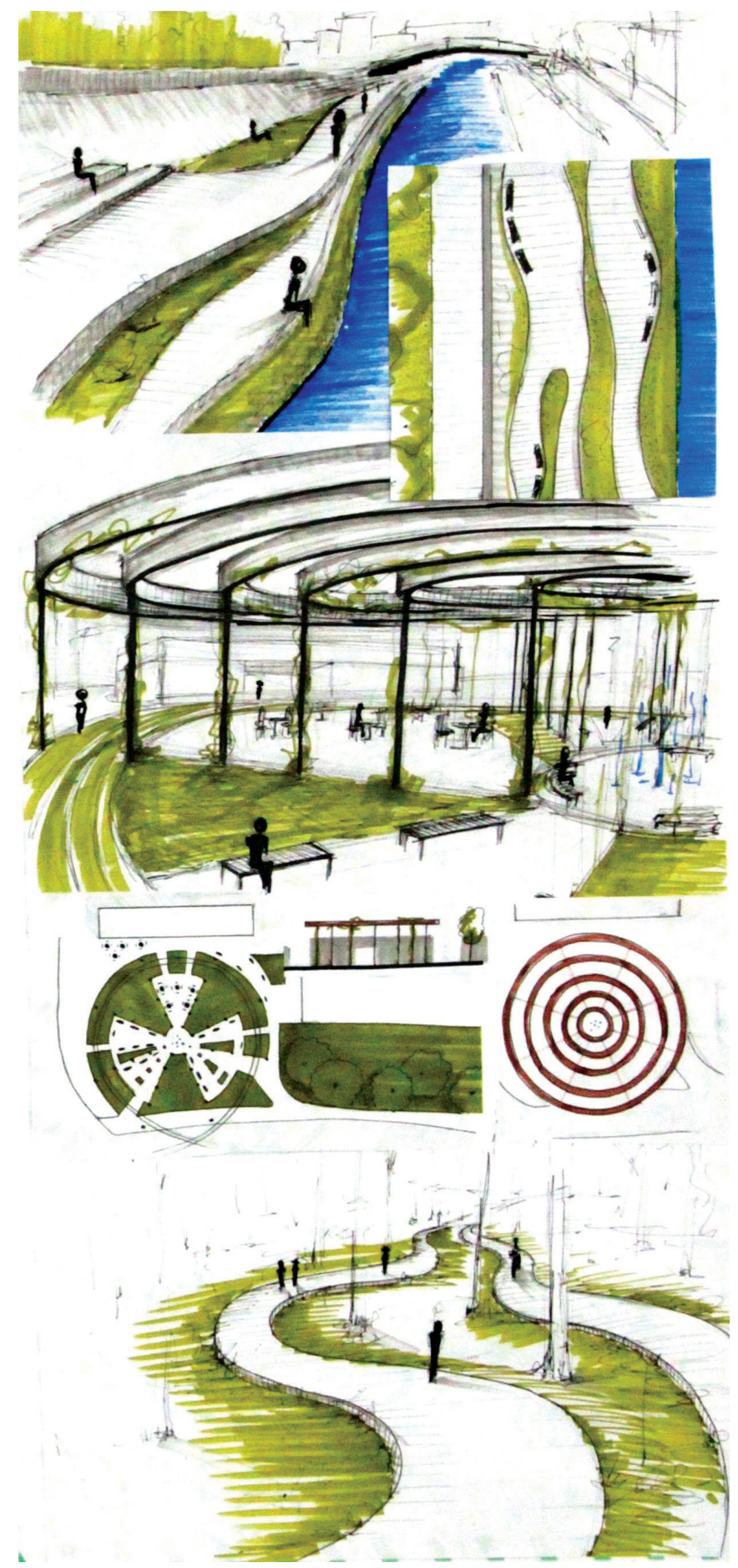

Fig. 4. The Entangled Salwator - design concept developed as a part of the Przepis na miasto workshop (by: Andrzej Bąk, Marcin Zaleski, Paulina Stopka, Paulina Ziętek, Angelika Spendel) 


\section{Conclusions}

The river is an inseparable element of the urban landscape. Its role is reflected throughout the history of the city's formation and development, from the choice of location, through spatial and functional development, to economic, political and cultural development. The riverside location of the city distinguishes it from other urban areas. Riverside areas emphasize the individual and unique character of riverside cities and become strategically important for the urban development of the city.

The revitalization of riverside areas is a challenge for the $21^{\text {st }}$ century. Many cities are currently in the process of turning towards the river. This process indicates a return to nature and the desire to commune with the nature of people living in cities, as well as to see the resulting benefits. Properly developed boulevards should become a link between the city and the river. Thanks to this, the urban space located above the watercourse gains a new value and becomes an attractive, vibrant part of the metropolis, encouraging to spend free time, rest, as well as gaining attractive places in economic terms.

Cracow sees the advantages of well-developed boulevards. The Cracow Urban Programs include strategies and projects of which aim is to return the city to the river. The authorities began to gradually implement the designated goals. Zabłocie Park - "Wisła Station" opening in May 2018 is the result of Cracow Urban Programs implementation. The city is definitely changing near the Zabłocie district, which is covered by the revitalization program. The city authorities should also remember about the other fragments of the Vistula River, not only those at Zablocie. During the Przepis Na Miasto workshops, students proposed implementing a strategy from Cracow Urban Programs on the boulevards at the Stare Dębniki and Salwator. Students also pointed to new ideas, e.g. additional shared cyclist-pedestrian footbridge between Stare Dębniki and Salwator.

\section{References}

[1] Czarnecka D., Relacja rzeka- miasto, Faculty of Architecture of Warsaw University of Technology, 2010.

[2] Drapella-Hermansdorfer A., Nadrzeczne bulwary, [in:] Rzeki, cywilizacja, historia, Katowice, 1998, 139-161.

[3] Jażdżewska I., Rzeki jako bariery w ksztattowaniu miejskiej sieci osadniczej Polski w świetle zastosowań systemów informacji geograficznej, 2011.

[4] Muszyńska-Jeleszyńska D., Tereny nadrzeczne w strukturze przestrzenno-funkcjonalnej Bydgoszczy. Problemy rozwoju i rewitalizacji ( $\mathrm{PhD}$ thesis), Adam Mickiewicz University in Poznan, 2012.

[5] Mydel R., Rozwój urbanistyczny miasta Krakowa po drugiej wojnie światowej, Wydawnictwo i Drukarnia „Secesja”, Kraków 1994.

[6] Pancewicz A., Rzeka w krajobrazie miasta, Gliwice, 2004.

[7] Chasseriau A., Peyon J.P., Le projet île de Nantes, ou comment la ville se réconcilie avec son fleuve, CESTAN, Université de Nantes, ESO - UMR 6590 CNRS, MSH ANGE GUÉPIN, Nantes, $\mathrm{Nr} 22,2004,41-50$. 
[8] Pancewicz A., Rola rzek $w$ rozwoju przestrzennym historycznych miast nadrzecznych, Woda w przestrzeni przyrodniczej i kulturowej. Prace Komisji Krajobraz Kulturowego, Vol. 2, 2003, 275-285.

[9] Szwed J., Wspótczesna rola bulwarów w mieście, Przestrzeń i forma, Vol. 16, 2016.

[10] Wolińska D., Sławiński K., Zmiany znaczenia rzeki dla ksztattowania przestrzeni miejskiej na przykładzie strumienia Cheonggyecheon w Seulu, [in:] Research Papers of Wrocław University of Economics, nr 467, 2017.

[11] Kierunki Rozwoju i Zarządzania Terenami Zieleni w Krakowie na lata 2017-2030, https:// dialogspoleczny.Cracow.pl/ (access: 16.04.2018).

[12] Miejski Program Rewitalizacji Krakowa, Urząd Miasta Cracowa, BIG, 2008.

[13] Strategia Rozwoju Krakowa „Tu chcę żć. Kraków 2030”, https://www.bip.Cracow.pl/?id=47 (access: 13.04.2018).

[14] Studium uwarunkowań i kierunków zagospodarowania przestrzennego Miasta Krakow, https:// www.bip.Cracow.pl/?bip_id=1\&mmi=48 (access: 13.04 .2018$)$.

[15] HafenCity Hamburg, http://www.hafencity.com (access: 16.04.2018).

[16] Interview of Kamil Czepiela from Ośrodek Działań Ekologicznych with Joanna Chrostek, http://www.woda.edu.pl/artykuly/Cracow_w_wodzie/ (access: 11.04.2018).

[17] Rudawa, http://pl.wikipedia.org/wiki/Rudawa_(rzeka) (access: 10.04.2018).

[18] https://www.cnu.org/publicsquare/2016/09/15/real-\%E2\%80\%98bilbao-effect\%E2\%80\%99 (access: 17.04.2018). 